\title{
EFFECTS OF BODY SIZE, SHAPE AND \\ COMPOSITION ON THE POSTURAL STABILITY IN
}

THE PRE-PUBERTAL GROWTH SPURT

EFEITOS DO TAMANHO, FORMA E COMPOSIÇÃO CORPORAL NA ESTABILIDADE CORPORAL DURANTE O SALTO PRÉ-PUBERTÁRIO

EFECTOS DEL TAMAÑO, LA FORMA Y LA COMPOSICIÓN DEL CUERPO EN LA ESTABILIDAD POSTURAL EN EL DERRAME DE CRECIMIENTO PREPUBERTAL

\author{
Carlos Marta (carlosmarta@ipg.pt)*|** \\ Daniel Marinho (marinho.d@gmail.com)*** \\ Mikel Izquierdo (mikel.izquierdo@gmail.com)**** \\ Pedro T. Esteves (ptesteves@ipg.pt)*|** \\ Ana Alves (anasofiaruivoalves@gmail.com) ***** \\ Mário Marques (mariomarques@mariomarques.pt)***
}

\begin{abstract}
Children aged 10-11 years go through a dynamic developmental period marked by rapid changes in body size, shape, and composition, all of which are sexually dimorphic. The purpose of this study is to analyze the effects of these factors on postural stability in the pre-pubertal growth spurt. This represents a cross-sectional study involving 312 children (152 boys, 160 girls), from 5th and 6th grade (10.8 \pm 0.4 years), who were self-assessed as belonging to Tanner stages I and II. Postural balance control was evaluated using the single-legged flamingo balance test. The ectomorphy, body mass and body height on postural stability were observed. Body fat variables, endomorphy and mesomorphy did not have a statistically significant influence. Additionally, boys and girls aged 10-11 years seem to display a similar performance. Determining these anthropometric and morphological parameters effects and gender differences in postural stability are important in many practical fields such as physical education and youth sport.
\end{abstract}

Keywords: balance, pre-pubertal, school, performance.

\section{RESUMO}

As crianças entre os 10 e 11 anos de idade experienciam uma fase de desenvolvimento com forte dinâmica, caracterizada por mudanças no tamanho corporal, na forma e na composição que, por sua vez, se associam a um claro dimorfismo sexual. O propósito deste estudo foi o de analisar os efeitos destes fatores na estabilidade postural durante o período pré-pubertário. Este estudo envolveu 312 crianças (152 rapazes e 160 raparigas) do 5o e 6o anos de escolaridade (10.8 \pm 0.4 anos), que se auto-avaliaram como pertencentes ao estádio I e II de Tanner. O controlo do equilíbrio postural foi avaliado a partir do teste unilateral do Flamingo. Os resultados indicaram um efeito significativo do ectomorfismo, massa corporal e altura na estabilidade corporal. As variáveis massa gorda, 
endomorfismo e mesomorfismo não apresentaram diferenças estatisticamente significativas. Em paralelo, observou-se um desempenho equivalente entre rapazes e raparigas. A possibilidade de avaliar o impacto dos parâmetros antropométricos e morfológicos, bem como o efeito das diferenças associadas ao género, poderá constituir-se como uma relevante fonte de conhecimento para o contexto prático de intervenção no âmbito da educação física e desporto para jovens.

Palavras Chave: equilibrio, período pré-pubertário, escola, desempenho.

\section{RESUMEN}

Los niños de 10 a 11 años pasan por un período de desarrollo dinámico marcado por cambios rápidos en el tamaño del cuerpo, la forma y la composición, lo que hacen que sean todos sexualmente dimorfos. El propósito de este estudio fue analizar los efectos de estos factores sobre la estabilidad postural en el brote de crecimiento prepuberal. Este fue un estudio transversal en el que participaron 312 niños ( 152 niños, 160 niñas), de 5 o y 6 grado (10,8 $\pm 0,4$ años), que fueron autoevaluados como pertenecientes a las etapas I y II de Tanner. El control del equilibrio postural se evaluó utilizando la prueba de equilibrio de flamingo con una sola pierna. Se observó un efecto significativo de la ectomorfia, masa corporal y altura corporal sobre la estabilidad postural. Las variables grasa corporal, endomorfia y mesomorfia no tuvieron influencia estadísticamente significativa. Además, los niños y niñas de 10 a 11 años de edad parecen tener un rendimiento similar. La determinación de los efectos de estos parámetros antropométricos y morfológicos y las diferencias de género en la estabilidad postural es importante para muchos campos prácticos, como la educación física y el deporte juvenil.

Palabras clave: equilibrio, prepuberal, escuela, rendimiento.

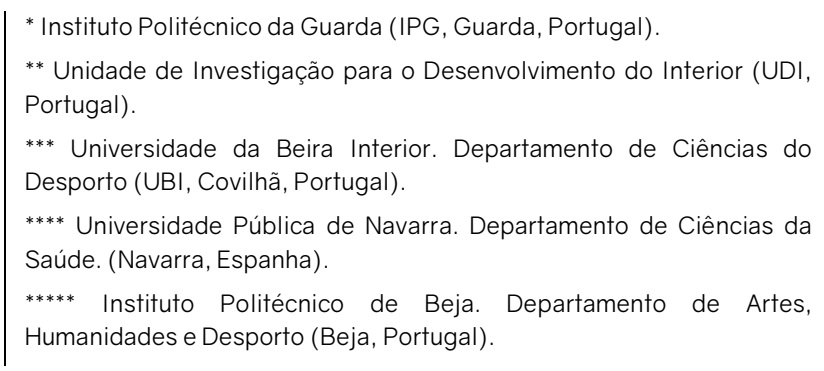

Submitted: 29th October 2018

Accepted: 1st April 2019 


\section{INTRODUCTION}

Postural stability refers to the inherent ability of a person to maintain, achieve or restore a specific state of balance and not to fall (Pollock, Durward, Rowe, \& Paul, 2000). The ability to maintain postural stability is an essential pre-requisite to competently perform most activities of daily living (Roncesvalles, Woollacott, \& Jensen, 2001). Furthermore, postural stability is considered to be an important indicator of musculoskeletal health and therefore could be of importance in view of clinical issues (Pollock et al., 2000). In children, balance is inextricably linked to motor development and fundamental movement skills (Fisher et al., 2005).

As balance abilities become refined during childhood, the factors influencing balance have been reported to include, among others (e.g. leisure preferences and development of visual, vestibular, and somatosensory systems), anthropometric and morphological parameters (Lee $\&$ Lin, 2007). What happens is that children aged $10-11$ years are going through a dynamic developmental period that is marked by rapid changes in body size, shape, and composition, all of which are sexually dimorphic (Malina \& Bouchard, 1991), and we believe that the effects of these factors on the postural stability in the pre-pubertal growth spurt require further clarification.

During this developmental stage, which precedes peak height velocity, the children show very great growth (about $20 \%$ of adult height) (Malina \& Bouchard, 1991). At this period, the growth and the great dimensional increase are not accompanied by muscle development because the effects of circulating androgens, particularly testosterone, only manifest themselves at puberty (Ramsay et al., 1990), which confers on the child a degree of weakness and hypotonia. Also, there is marked increase in subcutaneous adipose tissue during this period, which is more pronounced in girls (Malina \& Bouchard, 1991).

Some studies have shown that girls outperform boys on static and dynamic balance tasks. Lee and Lin (2007) speculated that the gender difference could have been due to the larger body weight of the boys. There is some evidence that excess body mass not only influences balance during the gait cycle but also affects postural control during standing and balance performance (Deforche et al., 2009). However this may not be the case if we consider that the height and weight growth curves in male and female intersect for a time, referred to as "crossing over", when girls overtake boys in stature and weight, a stage which coincides with pre-puberty (Malina \& Bouchard, 1991). Recently, Marta et al. (2012) reported a smaller size effect of gender on the static standing balance in elementary school children, and they hypothesized that could be due to the fact that in pre-pubertal period the difference in stature between boys and girls gradually decrease, due to the growth velocity of girls at this stage be higher than for boys, reaching the peak height velocity (PHV) earlier (Malina \& Bouchard, 1991).

A greater stature leads to a high body's center of mass, in turn responsible for increased postural instability on balance exercises (Allard, Nault, Hinse, Leblawc, \& Labelle, 2001). Furthermore, reported differences in body size, shape and composition are closely linked to the genetic determinism, observed from the morphoconstitutional point of view, and there is evidence that by pre-puberty the boys tend to show a slight increase of the mesomorphic (relative muscle-skeletal magnitude) values, and the girls show an increase of the endomorphy (relative adiposity) and a slight reduction of the ectomorphic (relative thinness) values (Malina, Bouchard, \& Bar-Or, 2004).

According to our best knowledge, no large sample reference studies and none studies that compared the influence of body size, shape and composition on postural stability in the prepubertal growth spurt have been reported. Therefore, the aim of this study was to investigate 
postural stability of prepubescent boys and girls in this dynamic developmental period and to determine how this was moderated by gender, anthropometric and morphological parameters.

\section{METHODS}

\section{Experimental Approach to the Problem}

Three hundred and twelve students were recruited from a Portuguese public school cluster to perform the single-legged flamingo balance test. Inclusion criteria were: children aged 10 to 11.5 years (5th and 6 th graders), who were self-assessed as belonging to Tanner stages I and II, with no chronic pediatric diseases or orthopedic limitations. All anthropometric and morphological measurements were carried out before the postural balance test. The singlelegged flamingo balance test was performed after a $10 \mathrm{~min}$ warm up period $(7 \mathrm{~min}$ running with intensity sufficient to raise breathe rate, 3 min stretching and joint specific warm up). All measurements were performed by the same investigator, in the first periods in the morning, and the testing assessment procedures were always conducted in the same indoor sportive facility (with temperature between 15으 and 18ㅇ) . The data collection lasted one month.

\section{Subjects}

The sample, cross-sectional in type, consisted of 312 prepubescent children (160 girls, 152 boys) all of whom volunteered for this study. The distribution of students according to their maturation stage was as follows: (i) girls: stage I, $53.1 \%$ and stage II, $46.9 \%$; (ii) boys: stage I, $81.6 \%$ and stage II, $18.4 \%$. Subjects were carefully informed about the design of the study and, subsequently, the children's parents signed an informed consent document prior to the start of the study. The experimental procedures were performed with compliance with the ethical standards as laid down in the Declaration of Helsinki. Anthropometric and morphological parameters and performance in the flamingo balance test were ascertained for all subjects (Table 1).

Table 1. Descriptive data of anthropometric and morphological parameters and single-legged flamingo balance test performance

\begin{tabular}{lrrrrrr}
\cline { 2 - 7 } & \multicolumn{2}{c}{ Boys } & \multicolumn{2}{c}{ Girls } & \multicolumn{2}{c}{ Overall sample } \\
\cline { 2 - 7 } & Mean & SD & Mean & SD & Mean & SD \\
\hline Decimal age (years) & 10.830 & .434 & 10.825 & .438 & 10.827 & .435 \\
\hline Body mass $(\mathrm{kg})$ & 41.264 & 8.740 & 38.982 & 8.618 & 40.094 & 8.739 \\
\hline Body height $(\mathrm{cm})$ & 145.26 & 7.408 & 144,38 & 8.744 & 144.81 & 8.119 \\
\hline BMl & 19.462 & 3.206 & 18.578 & 2.931 & 19.009 & 3.095 \\
\hline Body Fat $(\%)$ & 22.383 & 8.658 & 23.102 & 6.993 & 22.752 & 7.843 \\
\hline Endomorphy & 3.620 & 1.716 & 3.963 & 1.602 & 3.796 & 1.665 \\
\hline Mesomorphy & 4.693 & 1.161 & 3.685 & 1.092 & 4.176 & 1.232 \\
\hline Ectomorphy & 2.495 & 1.453 & 2.850 & 1.450 & 2.677 & 1.460 \\
\hline Flamingo balance (faults) & 9.342 & 5.793 & 7.687 & 5.742 & 8.493 & 5.817 \\
\hline
\end{tabular}

\section{Procedures}

Anthropometric and morphological measurements

All anthropometric measurements were assessed according to international standards for anthropometric assessment (Marfell-Jones, Olds, Stewart, \& Carter, 2006). Body mass (kg) 
was measured to the nearest $0.1 \mathrm{~kg}$ using a standard digital floor scale (Seca, model 841, Germany). Standing height was assessed with a precision stadiometer to the nearest $0.10 \mathrm{~cm}$ (Seca, model 214, Germany). For perimeter measurement a circumference tape was used (Seca 200). The bi-condyle femoral and humeral diameters were assessed (Campbell, 20, Ross Craft, Canada). The percentage body fat (\%BF) from skinfold anthropometry was calculated following Slaughter et al., (1988). As such, triceps and subscapular skinfolds were determined by internationally recommended methods (Marfell-Jones et al., 2006). The principal components of the morphological typology, endomorphy (END), mesomorphy (MES), and ectomorphy (ECT), were calculated using the method described by Heath \& Carter (1971). A girth measurement of the biceps and calf, corrected for using the skinfold measures was used. Maturity level based on Tanner stages (Tanner, 1962) was self-assessed.

\section{Testing procedures}

Postural balance control was evaluated using the single-legged flamingo balance test (Deforche et al., 2003). Subjects were instructed to stand on the preferred leg (with shoes removed) with their eyes open on a $3 \mathrm{~cm}$ wide and $5 \mathrm{~cm}$ high bar, while the free leg was flexed at the knee joint and held at the ankle joint close to the buttocks. One minute of stance was performed and the number of losses of balance (either by falling off the beam or letting go of the foot being held) was counted and used as a measure of postural balance. A 1 min period of familiarization was performed before the test. The Flamingo balance has shown an ICC of 0.93.

\section{Statistical Analyses}

Standard statistical methods were used for calculation of the means and standard deviations. The normality of the distribution was checked by applying the Kolmogorov-Smirnov test. The within-subject reliability of the postural stability test was determined by the intraclass correlation coefficient (ICC). To determine the effects of body size, shape and composition on the postural balance control it was estimated an analysis of covariance (ANCOVA), with gender as factor and body height, body weight, fat mass and somatotype as covariates. Statistical analyses were carried out by using the statistical packages for SPSS 17.0 for Windows (SPSS Inc., Chicago, IL, USA). The statistical significance was set at $p \leq 0.05$.

\section{RESULTS}

Through the ANCOVA, it was observed a significant but small-sized effect of the ectomorphy $(p=0.002$, Effect size $=0.032)$ on the postural stability, followed by body mass $(p=0.004$, Effect size $=0.027)$ and body height $(p=0.035$, Effect size $=0.014)$. The variables body fat $(p=$ 0.400 , Effect size $=0.002)$, endomorphy $(p=0.588$, Effect size $=0.001)$ and mesomorphy $(p=$ 0.116 , Effect size $=0.008$ ) did not have a statistically significant influence. (Figure 1)

Additionally, as expected, the boys had a greater number of faults ( $9.34 \pm 5.79$ faults) on the flamingo balance test than the girls $(7.69 \pm 5.74$ faults $)$. However there were no statistically significant effect of the factor gender $(p=0.337$, Effect size $=0.003)$ in the performance of this test. 


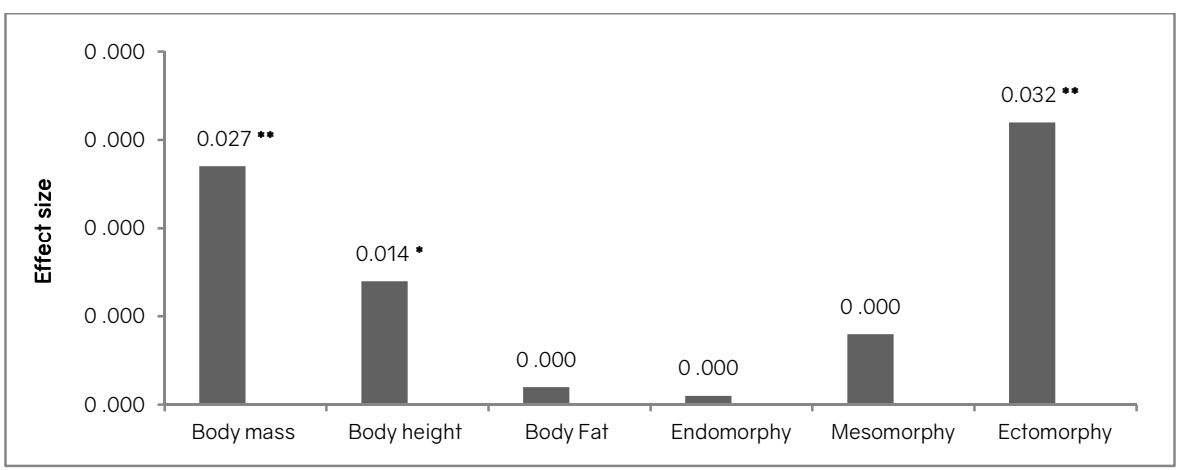

Figure 1. Effect size of body weight, height, fat mass percent, endomorphy, mesomorphy and ectomorphy on the postural stability $\left({ }^{*} p<0.01 ;{ }^{*} p<0.05\right)$

\section{DISCUSSION}

According to Rival, Ceyte, and Olivier (2005) investigating developmental changes of postural control in children with respect to standing balance, a transition phase should occur around 78 years. In 9 to 10 year olds standing balance appeared to be adult-like, however, not fully matured (Rival et al., 2005). After these ages, the children are in going through a dynamic developmental period, which precedes peak height velocity, marked by rapid changes in anthropometric and morphological parameters (Malina \& Bouchard, 2005). In this period, the results of our study seem to show a significant effect of body weight, height and ectomorphy on the postural stability, while the fat mass, endomorphy and mesomorphy seem to have no significant influence. Furthermore, boys and girls aged 10-11 years seem to have similar performance.

It is not clear what effects excess body mass has on postural stability of children (Deforche et al., 2009). Previous studies reported that increased body weight in children (McGraw, McClenaghan, Williams, Dickerson, \& Allard,2000) is associated with increased oscillations and likely increases the risk of falling. Additionally, a decrease in body weight leads to improved balance control (Teasdale et al., 2007). Deforche et al. (2009) showed that overweight children showed an inferior force production in raising the body to a standing position, due to insufficient leg strength to lift the excess body weight. They also had greater sway velocity in standing position, indicating that they have difficulties decelerating the forward trunk motion following the rise. This could also result from lower strength relative to mass. Another reason for suggesting that balance control is perturbed with increased body weight is that plantar mechanoreceptors may be less receptive due to the continuous pressure of supporting a large mass (Teasdale et al., 2013). However, some investigations that were performed on stable surfaces with individuals who were overweight or with normal body mass have shown that balance does not appear to be affected in such situations (Molikova et al., 2006; Chiari, Rocchi, \& Capello, 2002). More recently, Condon and Cremin (2014) also reported that correlations for weight and balance were only weak in the younger age groups (6-7-year-old age group), but not correlated in older ages ( $>10$ year).

Unlike the body weight, there is a consensus in the literature that increased height worsens balance. This is because a greater stature leads to a high body's center of mass, in turn responsible for increased postural instability on balance exercises (Lee \& Lin, 2007; Allard et 
al., 2001). Furthermore, Berger, Trippel, Dische, and Dietz (1992) have stated that ankle displacement and the response of the gastrocnemius increased with increasing height. In a recent study conducted by Alonso et al. (2012), the height was the anthropometric variable that most influenced postural balance.

There are few studies of body composition variables for comparative purposes. Mainenti et al. (2011) observed that elderly women with greater fat mass exhibited worse performance. Alonso et al. (2012) reported similar results in young adults, showing that the percentage of fat mass correlated negatively with the postural balance. In their study, the fat mass showed negative correlations with the mediolateral sway and the displacement velocity in the whole group. On the contrary, greater lean mass correlated with significantly greater postural control (Alonso et al., 2012).

Previous studies have identified height and weight as important factors affecting quiet standing stability but few studies have addressed body morphology as a global factor. The study of Lee and Lin (2007) showed that the mesomorphic, muscular children had significantly smaller mean radius of center of pressure distribution on a force platform than the endomorphic, fatty children and the ectomorphic, linear children during the single-leg upright standing postural stability test. For the authors, the explanation for somatotype differences might be due to the significantly lower body height and higher portion of muscular profile in the mesomorphic children. In this regard, some studies have proposed that muscular strength is important for balance control (Condon \& Cremin, 2014; Handrigan et al., 2010). In reverse, Allard et al. (2001) attributed the decrease in standing posture stability of the ectomorphic children to a relatively low muscle component, a high height weight ratio and an elevated position of the body center of mass.

Many studies have shown that girls outperform boys on static and dynamic balance tasks. In particular, the boys had significantly greater sway when standing on one leg than the girls (Mickle, Munro, \& Steele, 2011). It is possible that maturation of the neurological, visual, vestibular and proprioceptive systems occurs earlier in girls such that they can perform the complex task of balancing on one leg more efficiently (Cratty, 1970). Lee and Lin (2007) found similar gender differences in the postural stability of healthy children, whereby 9 - to 11-yearold boys displayed greater center of pressure excursion during a one-legged task than girls. The same authors speculated that the gender difference could have been due to the larger body weight of the boys; and this may be the case in the present study as the boys were slightly heavier than the girls (this difference was statistically significant). On the contrary, in the present study there was no significant difference in body height between boys and girls. This may be due to the fact that in pre-pubertal period the difference in stature between boys and girls gradually decreased, because the growth velocity of girls at this stage is higher than for boys, reaching the peak height velocity (PHV) earlier (Malina \& Bouchard, 1991). A greater stature leads to a high body's center of mass, in turn responsible for increased postural instability on balance exercises (Allard et al., 2001).

Regarding the morphological typology, the girls studied showed higher values of body fat percentage, endomorphy and ectomorphy compared with that shown by the boys. The ectomorphic component represents the relative thinness of the subject (i.e. relatively low muscle component and high height weight ratio) and therefore associates negatively with postural balance control (Lee \& Lin, 2007). Additionally, the endomorphic component expresses the degree of adiposity development (Malina \& Bouchard, 1991) inversely correlated with balance tasks (Lee \& Lin, 2007). However, as reported by Alonso et al. (2012) the women may have developed other strategies for maintaining balance that depended less on body composition. Peterson, Christou, and Rosengren (2006) suggested that pre-pubertal girls have better use of vestibular information and consequently reduce the body sway as 
compared to boys of the same age. Generally, boys lag behind with their physical growth as well as the development of their neuromuscular system.

Nevertheless, there are some limitations of the study that should be addressed : (i) due to the methodological approach, it was not possible to clarify the effect of other factors underlying the postural balance control (e.g., maturation of the neurological, visual, vestibular and proprioceptive systems); (ii) we have examined postural stability using field-based assessments. Different methods of evaluating postural stability (e.g., the use of a laboratorybased force platform) may lead to data bias; (iii) any differences in balance between genders can be environmentally induced (e.g. sex-role development) rather than biologically induced, such as different practice opportunities or the preference for activities that require more balance.

\section{CONCLUSION}

In brief, our data suggested that ectomorphy, body mass and body height influence postural stability. However, body fat, endomorphy and mesomorphy did not influence postural stability. Additionally, boys and girls showed similar performance on the postural stability. Determining these anthropometric and morphological parameters effects and gender differences in postural stability is important for many practical fields such as physical education and youth sport.

\section{CONFLICT OF INTEREST}

The authors have no conflict of interest in this study.

\section{REFERENCES}

Allard, P., Nault, M., Hinse, S., Leblawc, R. \& Labelle, H. (2001). Relationship between morphologic somatotypes and standing posture equilibrium. Annals of Human Biology, 28(6), 624-33.

Alonso, A. C., Luna, N. S., Mochizuki, L., Barbieri, F., Santos, S. \& Greve, J. D. (2012). The influence of anthropometric factors on postural balance: the relationship between body composition and posturographic measurements in young adults. Clinics, 67(12). 1433-41.

Berger, W., Trippel, M., Discher, M. \& Dietz, V. (1992). Influence of subjects' height on the stabilization of posture. Acta Oto-Laryngologica, 112(1), 22-30.

Chiari, L., Rocchi, L. \& Capello, A. (2002). Stabilometric parameters are affected by anthropometry and foot placement. Clinical Biomechanics, 17(9-10), 666-77

Condon, C. \& Cremin, K. (2014). Static Balance Norms in Children. Physiotherapy Research International, 19(1), 1-7.

Cratty, B. J. (1970). Perceptual and motor development in infants and children. New York: The Macmillian Company.

Deforche, B. I., Hills, A. P., Worringham, C. J., Davies, P. W., Murphy, A. J., Bouckaert, J. J. \& De Bourdeaudhuij, I. M. (2009). Balance and postural skills in normal-weight and overweight prepubertal boys. International Journal of Pediatric Obesity, 4(3), 175-82. 
Deforche, B. I., Lefevre, J., De Bourdeaudhuij, I., Hills, A. P., Duquet, W. \& Bouckaert, J. (2003). Physical fitness and physical activity in obese and non-obese Flemish youth. Obesity Research, 11(3), 434-41.

Fisher, A., Reilly, J., Kelly, L., Montgomery, C., Williamson, A. \& Paton, J. (2005). Fundamental movement skills and habitual physical activity in young children. Medicine \& Science in Sports \& Exercise, 37(4), 684-8.

Handrigan, G., Hue, O. M., Simoneau, M., Corbeil, P., Marceau, P., Marceau, S., et al. (2010). Weight loss and muscular strength affect static balance control. International Journal of Obesity, 34(5), 936-42.

Heath, B. H. \& Carter, J. E. L. (1971). Growth and somatotype patterns of Manus children, Territory of Papua and New Guinea: Application of a modified somatotype method to the study of growth patterns. American Journal of Physical Anthropology, 35(1), 49-67.

Lee, A. J. Y. \& Lin, W. H. (2007). The influence of gender and somatotype on single leg upright standing postural stability in children. Journal of Applied Biomechanics, 23(3), 173-9.

Mainenti, M. M., Rodrigues, E. C., Oliveira, J. F., Ferreira, A. S., Dias, C. M \& Silva, A. S. (2011). Adiposity and postural balance control: Correlations between bioelectrical impedance and stabilometric signals in elderly Brazilian women. Clinics, 66(9),1513-8.

Malina, R. M. \& Bouchard C. (1991). Growth maturation and physical activity. Champaign, Illinois: Human Kinetics.

Malina, R., Bouchard, C. \& Bar-Or, O. (2002). Growth, maturation and physical activity. Champaign, Illinois: Human Kinetics.

Marta, C., Marinho, D. A., Barbosa, T. M., Izquierdo, M. \& Marques, M. C. (2012). Physical fitness differences between prepubescent boys and girls. Journal of Strength and Conditioning Research, 26(7), 1756-66.

Marfell-Jones, M., Olds, T., Stewart, A. \& Carter L. (2006). International standards for anthropometric assessment. Potchefstroom, South Africa: ISAK.

McGraw, B., McClenaghan, B. A., Williams, H. G., Dickerson, J. \& Ward, D. S. (2000). Gait and postural stability in obese and non-obese prepubertal boys. Archives of Physical Medicine Rehabilitation, 81(4), 484-9.

Mickle, K. J., Munro, B. J. \& Steele, J. R. (2011). Gender and age affect balance performance in primary school-aged children. Journal of Science and Medicine in Sport, 14(3), 243-8.

Molikova, R., Bezdickova, M., Langova, K., Holibka, V., David, O., Michalikova, Z., et al. (2006). The relationship between morphological indicators of human body and posture. Biomedical Papers of the Medical Faculty of the University Palacky Olomouc Czech Republic, 150(2), 261-5.

Peterson, M. L., Christou, E. \& Rosengren, K. S. (2006). Children achieve adult-like sensory integration during stance at 12- years-old. Gait Posture, 23(4), 455-63.

Pollock, A. S., Durward, B. R., Rowe, P. J. \& Paul, J. P. (2000). What is balance? Clinical Rehabilitation, 14(4), 402-6.

Ramsay, J., Blimkie, C., Smith, K., Garner, S., Macdougall, J. \& Sale, D. (1990). Strength training effects in prepubescent boys. Medicine \& Science in Sports \& Exercise, 22, 605-14.

Rival, C., Ceyte, H. \& Olivier I. (2005). Developmental changes of static standing balance in children. Neuroscience Letters, 376, 133-6.

Roncesvalles, M. N. C., Woollacott, M. H. \& Jensen, J. L. (2001). Development of lower extremity kinetics for balance control in infants and young children. Journal of Motor Behaviour, 33(2), 180-92.

Slaughter, M. H., Lohman, T. G., Boileau, R. A., Horswill, C. A., Stillman, R. J., VanLoan, M. D., et al. (1988). Skinfold equations for estimation of body fatness in children and youth. Human Biology, 60(5), 709-23.

Tanner, J. M. (1962). Growth at adolescence. Oxford: Blackwell Scientific Publications. 
Teasdale, N., Hue, O., Marcotte, J., Berrigan, F., Simoneau, M., Dore, J., et al. (2007). Reducing weight increases postural stability in obese and morbid obese men. International Journal of Obesity, 37(1), 153-60.

Teasdale, N., Simoneau, M., Corbeil, P., Handrigan, G., Tremblay, A. \& Hue, O. (2013). Obesity Alters Balance and Movement Control. Current Obesity Reports, 2(3), 235-40. 